\title{
Türkiye Solunda Bir Figür Olarak Attila ilhan
}

\author{
Nazan Kahraman \\ Amasya Üniversitesi Merzifon Meslek Yüksekokulu \\ nazkahraman@gmail.com
}

\section{Öz}

Daha çok roman, șiir ve denemeleriyle Türkiye edebiyat dünyasının tanınmıș simalarından Attila ilhan, aynı zamanda yazdığı edebi metinlerin de yardımıyla sol düșünce içinde bir siyasal kișilik olarak kendine yer edinmiștir. Solcu șair ve yazarları okumanın suç sayıldığı 1940'larda, bu suçu ișlediği için devlet tarafından "solcu” ilan edilen illhan’ın, sol düșünce/hareket içinde aktif varlığı çok kısa sürelidir. Türkiye'deki baskı rejiminden kaçarak gittiği Fransa deneyiminin etkisiyle Kemalizm'e yönelmiș ve Kemalizm'i tüm düșünce dünyasının merkezine yerleștirmiștir. İlhan'ın düșünce dünyasının bir diğer belirleyeni, yine Fransa etkisiyle șekillenen kendine özgü diyalektik yöntemidir. Tüm zıt düșüncelerin birbirini mutlak içerdiğinden/içermesi gerektiğinden hareket eden yöntemi aracılığıyla illhan, çerçevesini Kemalizm'in çizdiği bir sol düșüncenin mümkün olduğuna, bir bașka ifadeyle Kemalizm ve sosyalizmin birbirini içerdiğine/kapsadığına inanır. Bu inançla kendisini, toplumu ulusal Türk sosyalizmi adını verdiği yeni bir kapsayıc Kemalist siyaset altında birleștirmeye adar. Bu, içinde kavram ve söylem olarak sosyalizmin olmadığı, antiemperyalist olması kaydıyla solcu, İslamcı ve milliyetçi tüm toplum kesimlerine hitap eden yeni bir Kemalizm okumasından bașka bir șey değildir.

Anahtar Kelimeler: Attila ilhan, sosyalizm, Kemalizm, antiemperyalizm, Ulusal Türk sosyalizmi

Makale geliș tarihi: 07.09.2015 • Makale kabul tarihi: 06.10.2015

http://ilefdergisi.org/2016/3/1/

ilef dergisi • (c) 2016 • 3(1) • bahar/spring: 91-119 


\section{Atilla illhan \\ as a Figure of the \\ Turkish Left}

Nazan Kahraman

Amasya University Merzifon Vocational School

nazkahraman@gmail.com

\section{Abstract}

Atilla Illhan, who is more widely known with his novels, poems and dissertations in Turkish Literature, has gained a place in leftist thought as a political character by means of his literary works. Illhan's active participation within leftist thought/movement was quite short during the 1940's, through which reading leftist poets and writers was deemed as a guilt and he was declared as "leftist" by the state as he engaged in such an activity. By the effect of his French experience after his escape from the repressive regime, he tended towards Kemalism and placed it into the center of his thinking. Other significant determinant of his thought is dialectic methodology shaped by his experience in France. By means of this methodology, which is derived from the idea that all opposite ideas contain/supersede each other, ilhan believes that leftist thought would possibly be framed by Kemalism. In other words, he believes that Kemalism and leftist thought cover/supersede each other. With this thought in mind, he dedicates himself to combining society under the new and inclusive Kemalist idea. This is nothing but a new kind of Kemalist reading that addresses to all social segments including antiimperialist leftists, Islamists and nationalists without any socialist implication.

Keywords: Attila Ilhan, socialism, Kemalism, anti-imperialism, National Turkish socialism.

http://ilefdergisi.org/2016/3/1/

ilef dergisi · C 2016 • 3(1) • bahar/spring: 91-119 
Türkiye solu, uzun yıllar baskı ve yasaklarla mücadele ettikten sonra, 1960'larla birlikte, gelişen demokrasi ortamının ${ }^{1}$ da etkisiyle, yaygın ve örgütlü bir harekete dönüşerek kendine oldukça geniş bir toplumsal alan açmayı başarmıştır. Bir taraftan aydınların önderliğinde başlayan ve geniş toplum kesimlerine hitap eden bir toplumsal hareket olarak siyasal hayatın gündemini meşgul eden "sol", diğer taraftan sendika tabanlı legal bir parti ile TBMM'de temsil edilmiştir. $^{2}$

Bugün Türkiye solunun sahip olduğu mirasın en önemli uğraklarından birisi olarak 1960'lar, solun Kemalizm, milletçilik ve sosyalizmi bir arada dillendirdiği yıllardır. ${ }^{3}$ Bu çalışmanın konusu olan Attila İlhan'ın da politik kimliğinin şair ve romancı kimliğinin önüne geçtiği; milliyetçilik, sosyalizm ve Kemalizm kavramları üzerinden antiemperyalizm ve bağımsızlık temelinde Türkiye'ye özgü sosyalizm kavrayışının olgunlaşmaya başladığı dönem 1960'lardir.

$\mathrm{Bu}$ çalışma, sosyalizm ile milliyetçiliğin birbirine karşıt değil birbirini tamamlayan kavramlar olduğu varsayımından hareket ederek milliyetçi öğeleri ağır basan bir Türk sosyalizmi kavrayışında olan Attila İlhan'ı konu 
almaktadır. Attila İlhan, sosyalizme ilişkin baskı ve yasakların en üst seviyede hissedildiği 1940'larda lise öğrencisiyken sosyalizm ile tanışmış ve bu tanışıklığın cezasını hapse girerek ödemiştir. Edebiyat dünyasında önemli bir figür haline geldiği 1950'lerle birlikte aktif olarak Türkiye solu içinde de var olmuştur. Fakat 1960'ların ortalarından itibaren Türkiye için ulusal sosyalizm üzerine yoğunlaşmaya başlayarak, kendini Türkiye solundan ayırma çabasına girmiştir. Hayatının sonuna kadar Türk ulusal sosyalizmi kavrayışı üzerine düşünen ve yazan İlhan; 2005 yılında öldüğünde teorisini Sultan Galiyev'in, pratiğini Kemalizm'in, çerçevesini “ulusal kültür sentezi”nin, tabanını tüm toplum kesimlerinin oluşturduğu bir "ulusal sol” üzerine sayısız yazı bırakmıştır. İlhan'ın ulusal sol kavrayışı, her ülkenin ekonomik, sosyal ve ideolojik gerçekleri ve bunlara uygun olarak da kendi sosyalist modeli olduğu/olması gerektiği üzerine temellenmektedir. İlhan bunu şöyle ifade eder: "Bir sosyalistin, eğer Türk sosyalistiyse, Marksizm'in metodunu kendi ulusal koşullarına uygulayarak oradan çıkaracağı tenkide göre davranışının olması lazım. Sağdan soldan alacağı bilgilerle bu iş olmaz. Halkının kabul edeceği formülü bulması lazım." ${ }^{4}$

Attila İlhan'ın ulusal kültür sentezi kavrayışı ışığında oluşturmaya çalıştığı "ulusal Türk sosyalizmi"nin eleştirel bir çözümlemesini yapmayı amaçlayan çalışma, İlhan'ın ulusal kültür sentezini nasıl ve hangi süreçte oluşturduğuyla ilgili olarak ilk bölümde kendisinin bireysel sosyalizm ilgisinin oluşması ve bu ilginin “Türk'e özgü bir sosyalizm” çabasına dönüşmesi sürecini irdeleyecektir. İkinci bölümünde ise İlhan'ın milli bir sosyalizm olarak Türk sosyalizmini hangi kavramlar üzerinden tanımladığı, bu sosyalizm teşebbüsüne hangi anlamları yüklediği ve bu kavrayışın Türkiye solunun neresinde olduğuyla ilgilenilecektir. Çünkü Attila İlhan'ın "ulusal kültür sentezi” olarak adlandırdığı tahayyülün nasıl oluştuğu ve hangi kavramlar üzerinden ifadelendirildiği, Türkiye solunun yaşanmışlıklarından çok uzağa düşmez.

\section{Attila İlhan'ın Düșünce Dünyasının Belirleyenleri}

Attila İlhan'ın ${ }^{5}$ Türkiye sol/ sosyalist düşünce ile arasındaki diyalog "vatanını sever gibi" sevdiği Nazım Hikmet ${ }^{6}$ üzerinden ve duygusal olarak kurulur. ${ }^{7}$ Ardından İlhan, sosyalizm ile arasındaki duygusal temelli bu ilişkiyi düşünsel temele yönlendirme gayretine girer ve Fransa'da sosyalizmi öğrenmeye çabalar. Aynı zamanda Kemalizm ve Mustafa Kemal'e ilgisi artan İlhan, yine Fransa'da kendi yöntemini geliştirir. 


\section{Attila ilhan'da Fransa Etkisi}

İlki 1949'da olmak üzere toplam üç Fransa seyahati yapan İlhan, ilk iki seyahatini Nazım Hikmet ile ilişkilendirmiştir. Kasım 1949'da “Nazım Hikmet' in kurtarılması" için gerçekleştirdiğini söylediği ilk seyahatinde sosyalizm, Marksizm ve Sovyet Marksizm'ini öğrenmeye çalıştığını söyler. ${ }^{8}$ Şubat 1950'de "hayatı ancak sosyalizmin düzelteceğini anlamış inanç düzeyinde bir sosyalist" olarak Türkiye'ye döner ve sosyalist hareket içinde aktif olarak yer alır. ${ }^{10}$ Esat Adil Müstecaplıoğlu tarafından 1950' de (yeniden) kurulan Türkiye Sosyalist Partisi'nde (TSP) ve partinin yayın organı olan Gerçek gazetesinde çalışır. ${ }^{11}$ Bir süre sonra İlhan 1951 ortalarında ${ }^{12}$ "Nazım'dan gelen habere göre gitmem gerek" ${ }^{13}$ diyerek tekrar Fransa'ya gider.

Fransa o dönemde edebiyat ve sanat dünyası için önemli bir mekân olmasının yanı sıra Marksist görüşlerin yaygınlık kazandığı ve Marks'ın Doğu toplumları üzerine yazılarının toplu olarak basıldığı bir yerdir. ${ }^{14} \mathrm{Bu}$ durum Fransa'yı sadece yarı sömürge durumunun nedenlerini arayan Türk aydınları için değil, kapitalizme karşı sosyalist bloğa yaklaşarak antiemperyalist mücadele ile sömürge durumundan kurtulmuş Afrika, Asya ve Latin Amerikalı gençler için de ilgi odağı yapmıştır. Fransa'da sosyalizm ile ilgilenen İlhan ayn zamanda üçüncü dünya ülkelerinin antiemperyalist ve milliyetçi sosyalizm deneyimlerinden, Mustafa Kemal ve Milli Mücadeleyi önemsemelerinden fazlasıyla etkilenmiştir. ${ }^{15}$ İlhan, bunu şöyle anlatır:

Ben, lise öğrenciliğim sırasında, Mustafa Kemal'i önemsemezdim pek! (...)'Beni bu işe sardıran, bilir misiniz ki, FKP üyesi bir Fransız arkadaşımdır. (...) sizin diyor, devrimci bir lideriniz olacak, adı neydi onun, Mustafa Kemal mi, nedir tutumu, Sunyatsen'e göre nereye koyabilirsin, sağa mı sola mı? Ana ilkeleri nelerdir? vs. Donakaldığımı hatırlıyorum. Söyleyebileceğim son derece genel, handiyse anlamsız şeyler. 19 Mayıs 1919 'da Samsun'a ayak bastı, memleketi düşmanlardan kurtardı falan filan. Bir anda, (...) ülkem, ülkemin devrimci lideri konusunda sorduklarını cevaplamakta aciz ve çaresiz kaldığımı görüp utanıyorum. ${ }^{16}$

Milli Mücadele ve Mustafa Kemal üzerine yoğunlaşan İlhan, Kemalizm'e yaklaştığı oranda "tahlil sosyalizmi" yapmakla suçladığ1 ${ }^{17}$ Türkiye solunu sorgulamaya başlar. "Kendi anladığı, bildiği sosyalizmi yapma" kararı ile Mart 1952'de ${ }^{18}$ Türkiye'ye döner. İlhan'ın tek başına, kendi bildiği şekliyle yapmaya çalıştığı Türkiye sosyalizmi, edebiyat ve sanat dünyasında "sosyal realizm" adıyla belirir. İlhan, aslında bu süreci, Fransa' da Aralık 1951-Mayıs 1952 arasında kendine özgü bir sosyalizm düşüncesinin temel belirleyeni ola- 
cak metodunun ilk dişa vurumu olarak nitelendirdiği ${ }^{19}$ ve "Kendi Kendine Sanat Konuşmaları" başlığıyla kaleme aldığı yazılarla başlatmıştır. Fakat bu yazılarda "sosyalizm" değil "Kemalizm" vurgusu vardır. ${ }^{20}$ İlhan'ın edebiyat ve sanat dünyasında "toplumsal, ilerlemeci ve devrimci" gerekçelerle başlattığı sosyal realizm (toplumsal gerçekçilik) hareketi, "milli, milliyetçi, Batılı, sosyal ve aydınlık bir sanat" amaçlamaktadır. ${ }^{21}$ Kendisine referans aldığı yöntemin ${ }^{22}$ sosyalist dünyaya ait olması nedeniyle sosyalizm bağlamında; kullandığı kavramlar ve işaret ettiği düşünce dünyası nedeniyle de milliyetçilik bağlamında ele alınan yöntemi, sosyalizm ve milliyetçilik arasında kalmakla eleştirilir. ${ }^{23}$ İlhan kendisine yöneltilen eleştirilere cevap olarak teorinin sosyalizmle bir ilgisi olmadığını, yapmaya çalıştığı şeyin, "gerçek Atatürkçülük ve "Kuvayı Milliye" ruhunu hareket noktası sayan, devrimci ve ulusal" bir sanat olduğunu söyler. ${ }^{24}$

Bu tartışmalar sürerken İlhan, 1963'ün ilk aylarında tekrar Fransa'ya gider. ${ }^{25}$ Nisan 1965 'te döndüğünde bütün enerjisini "ayakları yere basmayan Türk solu"na ${ }^{26}$ bir temel ve çerçeve oluşturmaya harcar. İlhan'ın oluşturmaya çalıştı̆̆ı çerçeve, 1950'ler boyunca dillendirdiği sanat ve edebiyatta "Türkiye'ye özgülük" ve yöntem sahibi olma zorunluluğunun sol düşünceye uygulanmasıdır. Yani İlhan'ın yazınında sanatta ulusal sentez yerini, sol düşüncede ulusal senteze bırakmıştır. Bu aslında bir yer değiştirme değil, siyasal hayatı içine alan kapsamlı bir toplum tasavvuru çabasıdır. Çünkü yönünü sosyalist teoriye değil, Mustafa Kemal ve Kemalizm'e çevirmiştir.

Bu kapsamda Fransa'da kaleme aldı̆̆ı yazılardan oluşan Hangi Batı (1972) başlıklı kitabı ${ }^{27}$ önemlidir. İlhan bu kitapta; "Batılılaşma”, "Batılı olma” ve "çağdaşlaşma" kavramları üzerinden Atatürkçülük ve Türkiye'nin Batılılaşması üzerine tartışmalar yapmıştır. Bu yazılardan birinde, Türk modernleşmesinin, "Bilimsel yöntemlerle geçmişimize dayanan, ondan yararlanan, fakat ileriye açılan ulusal bir bileşim" ${ }^{28}$ olacağını söylerken; bileşimin sınırlarını ise “Türk'üz, Türk kalacağız" şeklinde ${ }^{29}$ milliyetçilik ile çizmiştir. Diğer taraftan da kendisi bir modernleşme projesi olan Kemalizm ile sosyalizm arasındaki ilişkiyi izlemektedir. Çünkü İlhan; Atatürkçülüğün, uygarlıkçı, ilerlemeci nitelikleri bilime ve akla öncelik tanımasıyla, devrimci gelişmesinin bir

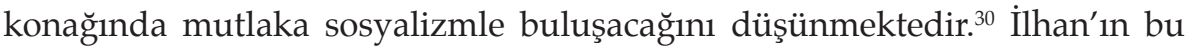
buluşmanın olacağına inancı, onun Fransa'da şekillendirdiği kendine özgü diyalektik yönteminden kaynaklanmaktadır. Uzun araştırmalar ve okumalar sonunda İlhan, sosyal olarak var olduğuna inandığı diyalektiğin, doğal ve bireysel olarak da var olduğunu öğrenmiştir. ${ }^{31}$ Bu yöntem, İlhan'ın günde- 
lik yaşam pratiklerini de kapsayacak şekilde ekonomik, toplumsal ve siyasal hayatın tamamına ilişkin bakış açısının temel belirleyeni olacaktır. Sosyalizm ve Kemalizm'i de bu yöntemle değerlendiren İlhan, bundan sonraki hayatını, kendine özgü diyalektik yöntemiyle ortaya çıkardığı solu/sosyalizmi, Mustafa Kemal ve Kemalizm üzerinden yeniden okumaya ve Türkiye'ye "öğretme" gayesiyle geçirecektir.

\section{Attila illhan'ın Koșullara Özgülüğü: Diyalektik Materyalizm}

İlhan, 1953 yılında kaleme aldığı bir yazıda, Batılı görüşlerle ulusal gerçeklerin birlikteliği olarak ulusal sentezin hem Doğu hem Batı kültürlerine yaslanan, hem modern hem geleneksel olması gerektiğini anlatırken, kendine özgü diyalektik yöntemini de şekillendirmiştir:

Her şeyden önce ulusal ve Türk olacaktır. Memleketçi ve milliyetçi olacaktır. Fakat aynı zamanda Batı sanat ve kültürünün şanlı geleneğini, aynı zamanda bütün Doğu İslam Türk sanatının ve kültürünün şanlı geleneğini iyice içine sindirmiş, eline Batılı ve uygar yöntemlerin anahtarını almış olacaktır. ${ }^{32}$

Kendi diyalektik yöntemini düşünce dünyasının temeline yerleştiren İlhan, Türkiye'ye özgü bir sosyalizmin de en temel sorununun yöntem sorunu olduğunu iddia etmektedir. "Kendi karşıtlarıyla çarpışa, birleşe gelişme" olarak tanımladığ $1^{33}$ diyalektik yöntemi, Türkiye'de öğrenemediğini söyler:

40’lı yıllarda, doğru dürüst kitap olmadığı için diyalektik metodun ne olduğunu öğrenemiyorduk; on yıl boyunca, rastladığım her sosyalist aydına ne demek olduğunu sordum, hiçbirisinden doyurucu bir cevap alamadım. Sosyalist sol ayd1nının "sosyalistliği", Sovyet tezlerini benimseyip tekrarlamasından ibaretti. Aynı şeyi daha sonra Mao'cular, aynı bezdirici ısrarla sürdürdüler. Diyalektik gibi, çevik ve esnek, üstelik akışkan bir yönteme sahip sosyalizm, kaskatı bir dogmatizm haline dönüştürülmüştü. ${ }^{34}$

Fakat İlhan, Türkiye'de gerek sosyalist bilgi düzeyindeki yetersizlik gerekse de Marksist yayınların olmaması nedeniyle öğrenemediği diyalektik yöntemi, Fransa'da bir işçi ile ayaküstü sohbetleri esnasında öğrenebilecektir. ${ }^{35}$ Çünkü İlhan'a göre aydın olmak bir yöntem sahibi olmayı gerektirmektedir. ${ }^{36}$ İlhan, yöntemini doğa bilimlerinden esinlenerek bir toplum mühendisi edasılyla şu şekilde somutlaştırır:

Diyalektik mantık: A, A ise B, A'nın 'karşıtı' ise, A, B'yi 'içerir'. Gece A ise, gündüz $B$ ise, bunların ikisi birbirini içerir; gün ağardığı anda, gerçekte, gece olmaya başlamıştır; hayatla ölüm, birbirinin kesinlikle karşıtıdır ama, ikisi birbirini içerir, 
çünkü doğduğumuz andan itibaren ufak ufak ölmek sürecine girmişizdir. Sosyalizm ve liberalizm de öyle; ikisi birbirinin 'karşıtı' dır ama ikisi birbirini 'içerir'. ${ }^{37}$

İlhan'ın yöntem kaygısı ve kendine özgü olma çabası, kendi sosyal gerçekliğini üretme gayretine dönüşmüştür. Öyle ki; kadının erkeği, iyinin kötüyü, aşkın nefreti barındırdığı şeklindeki algısıyla hayatı anlamlandırmaya çalışan İlhan, toplumsal yaşamda bir değişim/dönüşüm tasavvuru barındıran siyasal düşüncelerin aynı anda mutlak karşıtını barındırdığı savından hareket etmekte ve bu biraradalığı / karşıtlığ “ "tek"lik ile açıklamaktadır. Cinsiyet kavramında en görünür ifadesini bulan bu tek olma durumu için şunları söyler:

Birey de aynı karşıtlıklar sistemi içinde bir karşıtlık sistemidir. Hatta doğal, diyalektikte insanın kendi kendisini reddi. Yani nasıl oluyor: sen kadınsın ama aynı zamanda erkeksin. Çünkü sende erkeklik hormonları da var. Sende erkeklikten birçok özellik var. Öteki de erkek ama aynı zamanda kadın. Çünkü erkeklik hormonu yanında kadınlık hormonu da taşıyor ve bunlar değişken; durmadan azalıp çoğalıyor. ${ }^{38}$

İlhan'ın her olaya, her duruma karşıtıyla birlikte bakmak ve karşıtını kendi içinde aramak/bulmak şeklindeki yöntemi, kavramsal bir tartışmadan önce Kemalizm'in sosyalizmi içerdiğini varsaymasına neden olmuştur. Sosyalizm öngörmemesine rağmen ilerleme misyonu nedeniyle sosyalizm barındıran Kemalizm, aynı zamanda sosyalist devrimin karşıtı olması nedeniyle de onu içermektedir. ${ }^{39}$ Diğer taraftan Kemalist Devrim, sosyalist olan Rus Devrimi ile burjuva demokratik devrimi olan Fransız Devrimi'nin bir sentezi olarak; içinde hem sosyalizm hem liberalizm hem de demokrasi barındırmaktadır. ${ }^{40}$ Yani İlhan'a göre diyalektik doğrultusunda Kemalizm, "karşıtlık”, "sentez" ve "ilerleme" kavramları üzerinden sosyalizmi içermektedir. ${ }^{41}$

İlhan'ın yöntemi aracılığıyla ulaştığ1 bu tespitleri, onun solun/sosyalizmin Marksist yorumundan daha çok Fransız İhtilali sonrası ortaya çıkan siyasal söylem olarak tarihsel "sol"a yakınlaşmasına neden olmuştur. Bu yakınlaşmaya uygun olarak da Türkiye sosyalizminin imkânsızlık koşullarını tartışırken Marksist literatüre, mümkünlük koşulları ve kendine özgülüğü için ise ikinci Fransız İhtilali olarak değerlendirdiği Kemalist Devrim'e gitmektedir. İlhan'ın, kendine özgü diyalektik yöntemi aracılığıyla oluşturduğu, Kemalizm'i yönelim olarak sol, felsefe olarak sosyalizm ve burjuva demokratik devrimlerinin sentezi şeklindeki kavrayışı; onun ulusal sol kavrayışının sosyalizmden uzaklaştıkça ve Kemalizm'e yaklaştıkça hala "solda olmak" ve "sosyalist olmak" iddiasını meşrulaştırmıştır. 


\section{Attila İlhan'ın Ulusal Sosyalizminin Özellikleri}

Attila İlhan, Türkiye'yi içinde bulunduğu yarı bağımsız halinden kurtarmak ve kalkınmayı sağlamak amacıyla 1960'ların başından itibaren "sol"un gündemini meşgul eden Türkiye'ye özgü sosyalizm tartışmalarına, Mustafa Kemal ve Kemalizm'in kutsallığını Milli Mücadele'nin romantizmi ile birleştirerek, Türk milliyetçiliği esasına dayanan bir sosyalizm tahayyülü ile ve geç dönemli olarak katılmıştır. ${ }^{42}$ Çünkü bu tartışmaların yapıldığı dönemde İlhan'ın öncelikli ilgisini çeken konular, Türkiye sosyalizmden ziyade, sosyalizmin mutlaka "insancı ve özgürlükçü" olması gerektiği savunusundan hareketle Stalinci sosyalistliğin eleştirisidir. Sovyet sosyalizmini Marksist sosyalist literatüre göre eleştiren bu yazılarda "Marks'a dayanarak sosyalizmi yeniden tanımlamak gerekiyor" ${ }^{43}$ düşüncesi ile mevcut sosyalist uygulamaları Marx'a dayanarak irdelemektedir. Fakat yine de İlhan'ın sürmekte olan tartışmaya yabancı olduğunu söylemek doğru olmaz. Çünkü İlhan'ın sosyalist hareket içindeki ilk (ve tek) aktif dönemi, Türkiye'ye özgü, yerli bir sosyalizm anlayışının ilk savunucularından Esat Adil Müstecaplıoğlu'nun ${ }^{44}$ partisi olan TSP içindedir.

İlhan, "sosyalizm, diyalektik metot ve işçi sınıfının bir bileşimdir; bileşenin biri olmadı mı, olmaz" ${ }^{45}$ dese de Türkiye'ye özgü sosyalizmin bileşenleri olarak antiemperyalizm ve bağımsızlıkçılığı saymaktadır. Bunlara Türkiye solunda silahlı mücadelenin belirginleşmeye başlamasını takiben "anayasal" kavramını da ekleyerek, antiemperyalist ve bağımsızlık temelinde milli ve milliyetçi; kapsayıcılık iddiası ile “Kuvayı Milliye"'ye dayalı, Kemalizm'e ve onu koruyan Kemalist kanunlara bağlılık anlamında anayasal platformda bir sosyalizm $^{46}$ olarak belirlemiştir. İlhan'ın Türkiye'ye özgü sosyalizm için yönünü sadece Kemalizm'e çevirerek, Kemalist kavramlarla da bir sosyalizm tahayyül etmesinin nedeni, Marks'ın söylem ve kavramlarının hem teorik hem de pratik olarak Avrupa dışındaki ülkeler için gerçekliğinin olmadığını düşünmesidir. Bunu kendisiyle yapılan bir röportajda şöyle anlatır:

Marks diyor ki, Zincirlerinizden başka kaybedecek hiçbir şeyiniz yok. Dünya işçileri birleşiniz. Dünya işçileri derken, Marks'ın kafasındaki dünya, Avrupa'dan ibaret. Tipik 19. yüzyıl Avrupa aydını. Öbürleri sömürge, onları insandan saymıyor. (...) Marks'ın söylediklerinde çok ciddi hatalar var. Önümüzdeki yüzyıl proletaryanın yüzyılı olacaktır ve sosyalizm olacaktır diyor. Hâlbuki sonraki yüzyıl antiemperyalist savaşların yüzyılı ve sömürgeciliğin sonu oluyor". ${ }^{47}$ 
İlhan'ın, Marksist sol literatür ile Türkiye gerçeklerinin örtüşmediği düşüncesi, Türkiye gerçeklerine daha fazla kafa yormasına, Milli Mücadele ve Kurtuluş Savaşı üzerinden Kemalist Devrim okumalarını derinleştirmesine ve Türkiye solunun izlerini buralarda aramasına neden olmuştur.

\section{Milli, Milliyetçi, Kemalist Türk Sosyalizmi}

Attila İlhan, evrensel niteliklerini kaybetmeyen "yerli bir sosyalizm"48 değil, merkezinde "sınıf" yerine, "ulus" kavramının yer aldığı, milliyetçi öğeleri ağır basan tamamen Türk'e özgü, milli bir sosyalizmden yanadır ${ }^{49}$ ve sosyalizmin ulusallaşmasının kaçınılmaz olduğunu düşünmektedir. ${ }^{50}$ Türkiye'nin sosyalizmi, kendi koşulları içerisinde, kendi diyalektiğine göre olacaktır ${ }^{51}$ diyen İlhan'ın Türkiye'ye özgü bir sosyalizm için yazmaya başladığı dönem, Türkiye' de böylesi bir tartışmanın oldukça geniş toplum kesimleri tarafından yapıldığı ve kavramsal karşılıklarını neredeyse bulduğu bir dönemdir. Yani, İlhan'ın Kemalizm dolayımıyla Türkiye gerçekleri teması üzerinden ve oldukça geç dönemli taraf olduğu tartışma; sosyalizmin, Atatürk devrimlerini geliştirme ve ileri götürme yolu olduğuna inanan ${ }^{52}$ ve Kemalizm'in altı okunu, Türk sosyalizminin temel taşları olarak gören Yön Hareketi'nin ${ }^{53}$ gündeme getirdiği bir tartışmaydı. İlhan'ın, 1966'da Yön'de, “Yüz demokrasi varsa yüzü de ayrı, on sosyalizmin onu da ayrı yoldan ilerliyor. Türk sosyalizminielbet bilimsel yöntemlerle- ama Türkiye gerçeğinden çıkaracağız" ${ }^{\prime 54}$ diyerek taraf olduğu tartışmada, benzer fikirler daha önce dile getirilmişti ve dağında da Kemalizm vardı. Ataöv"55, "Her rejim kendi toprağında ve kendi şartlarına en uygun şekilde yeşerir. Türk sosyalizmi, bu tartışmaların sonunda ortaya çıkacaktır" derken; Uğur Mumcu ise Cumhuriyet'te “Türk sosyalizmi ne Marx'ın sosyalizmine benzemeli, ne de batı sosyalizminin bir kopyası olmalı. Memleket şartlarının yarattığı ve siyasi rejime en uygun" olmal1 ${ }^{56}$ diyordu. Programında Atatürkçülük vurgusu yapan ve Atatürk'ün emek üzerine yaptığı bir konuşmayı programına alan TİP ise, Atatürk milliyetçiliğini benimsediğini ${ }^{57}$ belirtmektedir. Kemalizm'i sosyalizm için ittifak gücü olarak gören Milli Demokratik Devrim (MDD) hareketi ise ${ }^{58}$, Kemalizm'in milliyetçi, antiemperyalist ilkelerinin Türkiye' de sosyal adaletin gerçekleştirilmesiyle sıkı sıkı bağlı olduğunu düşünmektedir. ${ }^{59}$ Her toplumun kendine özgü tarihsel koşulları ve kendi gerçeklikleri olduğunu belirten Aybar ${ }^{60}$, sosyalizmin bu koşullara göre oluşması gerektiğini ve taklitçilikten kaçınılması gerektiğini söylüyordu. Bunun yanı sıra meseleye, ülke gerçekleri yerine sosyalist teori açısından bakan, Kemalizm'i reddetmeyen ve Türkiye'ye özgü bir sosyalizm arayışının sosyalizmden uzaklaşmak olacağını düşünenler de mevcuttu. Bun- 
lardan Aren ${ }^{61}$, bakış açısının sosyalist temelli olması ve metodu öncelemek gerektiğini vurgularken; Erdost ${ }^{62}$, Türkiye sosyalizmi benzeri kavramların sosyalizmin taktik ve stratejilerinin dışına çıkılması tehlikesi doğuracağını söylemektedir.

İlhan'ın Türk sosyalizmi kavrayışının en önemli kavramı, milliyetçiliktir. Türkiye' nin kendine özgü koşullarını koruyan bir bağ olduğuna inandığı milliyetçiliği ulus devletle ilişkisi dolayısıyla merkeze alan İlhan ${ }^{63}$, Türk sosyalizminin işçi sınıfının yeterince gelişemediği ülkelerde olduğu gibi ancak milliyetçilik üzerinde oluşup gelişebileceğini savunur. Milliyetçilik söyleminin temel belirleyeni antiemperyalizm üzerinden iktisadi ve siyasi bağımsızlık olan İlhan'ın kavrayışının, milliyetçiliği antiemperyalizm ve antikapitalizmle mücadele ve iktisadi kalkınmanın bir aracı olarak gören 1960'lar sol düşüncedeki milliyetçi söylemden uzağa düştüğü söylenemez. Ayrıca temelde işlevi bu şekilde sabitlendikten sonra, milliyetçiliğin ilerici-gerici ayırımı üzerinden tartışılarak toplumun hangi kesiminden olursa olsun "ilericiler"in milliyetçiliğinin öne çıkarılması durumu İlhan dâhil tüm solda mevcuttur. Şöyle ki, gerek İlhan'ın gerekse mevcut solun milliyetçilik tanımlamaları, antiemperyalist, antikapitalist ve antifeodal bir savunmanın aracıdır. İlhan'ın çoğunlukla Milli Mücadele ve “Gazi Paşa” olarak Atatürk'ün şahsıyla özdeşleştirdiği milliyetçilik, Türkiye'nin ekonomik, sosyal, siyasal ve -Türkiye solundan farklı olarak- kültürel varlığını koruması ve geliştirmesi için en önemli "bağ"dır. Türkiye Cumhuriyeti öncesi mirası kapsayan ve o miras üzerine bir sentezi içeren ulusal kültür sentezi kavrayışı ile İlhan, kültürel yaklaşımı ve dolayısıyla kültür ve milliyetçilik kavramsallaştırmasında Türkiye solunda ayırıcı bir konum işgal etmektedir. Kendisi bu durumu şöyle ifade eder:

Oysa bilinçli bir ulus demek, ulusal kültürü olan bir ulus demek. Ortalıkta bir ekonomik sözüdür sürüp duruyor, ekonomik bağımsızlık iyi ama onun özrüne sığınıp siyasal bağımsızlığı yozlaştırmak, halkların köklü yaratıcılığını kontrol altına almak kötü. (...) Ekonomik milliyetçiliği bir ilericilik sayan bu altı kaval üstü şişhane aydınlar, kültürel milliyetçiliği gelenekçiliğe kaymak diye alıp düpedüz gericilik sayıyorlar. ${ }^{64}$

İlhan'ın sağcıların ümmet yanlısı, solcuların yabancı hayranı ve öykünmeci olarak tespiti üzerinden ilerici-gerici, iyi-kötü ve faydalı-zararlı kavramsallaştırmalarla ifade ettiği milliyetçiliğinde, ilerici / iyi / faydalı olabilmesinin ölçütü ise; ulusal bileşimi yapabilmek, yani yöntemi Avrupa'dan, mirası kendi varlığından, milletinden alabilmektir. 
Aynı şekilde, kendilerini Kemalizm'e bağlı milliyetçi aydınlar olarak tanımlayan ${ }^{65}$ ve milliyetçiliği iktisadi kalkınmanın aracı olarak gören Yön'ün milliyetçilik vurgusu, emperyalizm ve onun işbirlikçileriyle mücadeleyi içermektedir. ${ }^{66}$ Türkiye'de olası bir çatışmanın sınıflar arasında değil, ilericilergericiler arasında olmasını isteyen Yön, Atatürk ve Atatürkçülüğe bağlı Milli Cephe yanlılarını gerçek vatanseverler olarak ilerici şeklinde tanımlarken; toplumun her kesiminden ilerici kuvvetlerin bu platformda yerlerini almalarını ister. ${ }^{67}$

Burada belirtilmesi gereken ileri(ci) milliyetçiler ve geri(ci) milliyetçiler ayrımı ile işaret ettiği toplumsal kesimler, İlhan'ın bu konudaki yazılarını kaleme aldığı döneme bağlı olarak farklılaşabilmektedir. Daha açıkça ifade etmek gerekirse, İlhan'ın sosyalizm kavrayışı ve dolayısıyla milliyetçilik ve Kemalizm bağlamındaki düşüncelerinin benzerlik ve farklılığı bağlamında bu araştırmada ilişkilendirilen "sol”, 1960'lara aittir. Oysa İlhan'ın bu konulardaki düşünceleri için referans gösterilen yazıları, 1960'ların sonu ve yaygın olarak 1970'lere aittir. Türkiye solu için 1970'ler, Kemalizm ve milliyetçilikle arasına mesafe koyan, daha fazla özgürlük için mücadele eden gençlerin ve sermaye karşısında belirginleşen işçi sınıfının desteğine bağlı olarak kitleselliği artan ve en önemlisi silahlı mücadelenin gündemine girdiği yıllardır. ${ }^{68}$ Attila İlhan için ise bu yıllar, tek kişilik cephesinden sol ile adeta hesaplaşmasıyla ve solun neden öteki ve yanlış olduğu, kendisinin neden tek doğru olduğunu ispatlama çabasıyla geçen yıllardır. Bir başka ifadeyle, solun Kemalizm ile ilişkisi bağlamında 1960'ların bıraktığı yerden başlayarak/devam ederek 1960'larla bir tür halef-selef ilişkisi yaşamaya başladığı yıllardır. Çünkü 1970'lere referanslarının büyük bir kısmı değişen ve farklı fraksiyonlara giren Türkiye solunun 1960'lardaki referansları, İlhan için hala geçerlidir. İlhan bu referansları, kendisine özgün bir konum kazandıracak şekilde yüzyılın sonuna kadar ulusal sentez kavrayışı bağlamında savunacaktır.

Attila İlhan, söyleminde süreklilik arz eden Kemalizm vurgusu nedeniyle Türkiye solunda özgün bir konuma sahiptir. Bununla birlikte, sosyalizm ve Kemalizm arasında milliyetçilik üzerinden kurduğu olumlu ilişkinin geri planında antiemperyalizmin varlığına ilişkin tespitleri, Türkiye solunda da mevcuttur. Laçiner'e göre ${ }^{69}$ yurtseverliği içselleştirdiği ölçüde emperyalizm-antiemperyalizm eksenine sıkışması nedeniyle; Aydın'a göre ${ }^{70}$ Türkiye Cumhuriyeti'nin antiemperyalist bir programa bağlı olması nedeniyle, Türkiye solunun milliyetçilikle ilişkisinin temel belirleyeni antiemperyalizmdir. Toplumun emperyalizm olarak ortak düşmana karşı oluşturduğu "Kuvayı 
Milliye", birlik olma halinin ilk referansıdır. Türkiye solu içinde belki de en çok üzerinde uzlaşma sağlanan konu, antiemperyalist mücadelenin başlang1cının Kurtuluş Savaşı olduğudur. Dolayısıyla solun Attila İlhan'ı da içine alacak şekilde antiemperyalizm kavramını başlattığı yerden tartışmak, İlhan'ın ulusal sosyalizminin en temel öğesi olan antiemperyalizmi anlamak bakımından faydalı olabilir.

\section{Türk Sosyalizminin İtici Gücü Antiemperyalizm}

Türkiye solunda olduğu gibi, Attila İlhan'ı da milliyetçi düşünceye en çok yaklaştıran ve dolayısıyla sosyalizm ve Kemalizm arasında Kurtuluş Savaşı üzerinden kurulan olumlu ilişkiye aracılık eden kavram antiemperyalizmdir. ${ }^{71} \mathrm{Bu}$ ilişkinin meşruluğunda Kurtuluş Savaşı ve Kemalist hareketin Sovyetler Birliği ve komünist enternasyonal tarafından antiemperyalist olarak değerlendirilmesinin ${ }^{72}$ payı büyüktür. Bunu doğrulayacak şekilde İlhan, metinlerinde Lenin'in Türkiye'nin antiemperyalist Milli Mücadele' deki başarısı$\mathrm{n}$ ifade eden sözlerine oldukça fazla yer verir.

Attila İlhan'ın antiemperyalizm kavramı ile tanışması, kavramın Türkiye' de ortaya çıktığı sürecin ${ }^{73}$ izlerini taşır. İlhan, Birinci Dünya Savaşı sonrası yaşanan Anadolu işgalleri ve bu işgallere karşı yürütülen Kurtuluş Savaşı'na dair ailesinden dinlediği kahramanlık hikâyeleri ile "işgale karşı direniş" üzerinden gelişen milliyetçi bir tavırla antiemperyalizm ile duygusal bir ilişki kurmuştur. ${ }^{74}$ Düşünsel olarak antiemperyalizm kavramı ile tanışması ve onu sosyalizm ile ilişkilendirmesi ise İkinci Dünya Savaşı'ndan sonra dünyanın birçok yerinde sömürgelere karşı sosyalizmin desteği ile bağımsızlık savaşı veren ülkelerin başarısı bağlamında antiemperyalizm ve sosyalizm arasında kurulan ilişkinin ${ }^{75}$ izlerini taşır. İlhan'ın, 1960 başında Fransa'da üçüncü dünyacı gençler aracılığıyla farkına vardığı bu ilişki ${ }^{76}$, onun Milli Mücadele, Mustafa Kemal, “Kuvayı Milliye”, Müdafaa-i Hukuk gibi kavramlarla sol/sosyalizm kavramlarını birlikte düşünmesine neden olmuştur. İlhan, Mustafa Kemal'in devrimci, antiemperyalist, üçüncü dünyacı ve solcu bir lider; Kurtuluş Savaşı'nın da emperyalist Batı'ya karşı yürütülen ilk antiemperyalist mücadele olduğu sonucuna varmıştır. ${ }^{77}$ İlhan'ın Fransa' da önemsediği bu durum, söz konusu dönemde Kemalist Devrim'in sürekliliğini yitirdiğini ve Türkiye' nin tekrar emperyalist tehdit ile karşı karşıya kaldığını düşünen Türkiye solu ${ }^{78}$ için temel ve ortak söylemlerden birisidir ve odağında ikinci Kurtuluş Savaşı çağrısı vardır. ${ }^{79}$ Diğer taraftan, bu savunma durumunun veya milli kurtuluş hareketi şartlarının nasıl ve hangi tarihsel dönemde ortaya çıtığına ilişkin yapılan tespitler, Türkiye'nin, İkinci Dünya 
Savaşı sonrası ve özellikle Demokrat Parti iktidarı ile birlikte "milli" olanın yerine "yabancı" olanı tercih ederek ${ }^{80}$ ve yeni sömürgeciliğin hizmetine girerek yarı sömürge durumuna geldiği şeklindedir. ${ }^{81}$ Böylesi bir durum tespiti Attila İlhan'da da mevcuttur:

Kemal Paşa ve arkadaşlarının, yabancı sermayesine karşı, tam bağımsız bir ekonomiden, sanayileşmeden yana tutumları, demokrasi döneminin getirdiği 'hürriyet'le birlikte yabancı sermayeyi teşvik kanununa, petrol kanununa, Amerika ile ikili anlaşmalara dönüşüyor. (...) Kemal Paşa'nın kan ve ter pahasına ele geçirir gibi olduğu 'milli iktisat' devri gümbürdemiş gitmiş, yeniden yarı sömürge statüsüne dönmüşüz. ${ }^{82}$

Bununla birlikte "Gazi'yi kaybedince ray değiştirdik"83 diyen İlhan, devrime ilişkin kırılmanın tarihsel dönemini bir adım daha geriye götürerek Mustafa Kemal'in ölümünün ardından ve İsmet İnönü ile başlatır. İlhan'a göre Atatürk'ten sonra Kemalizm'den uzaklaştırılan ve antiemperyalizmin unutturulduğu Türkiye, tekrar emperyalist tehditle karşı karşıya kalmış ve tekrar bağımsızlık sorunu yaşamaya başlamıştır. ${ }^{84}$ İlhan, "İnönü Cumhuriyeti" ya da "yeni Tanzimatçılık" olarak adlandırdığı bu tarihsel dönemin tek sorumlusu olarak İnönü'yü gösterir. ${ }^{85}$

İlhan'ın sosyalizm aracılığıyla karşılaştığı antiemperyalizm kavramı, İlhan'1 “Önce Mustafa Kemal'i ve Kemalizm'i tanımış olsaydım, sosyalist düşünceye ilgi duymazdım”"86 diyecek kadar Kemalizm'e yaklaştırmıştır. Bu yaklaşma hali, İlhan'ın düşünce dünyasının merkezine Mustafa Kemal'i ve Kemalizm'i yerleştirmesine, Mustafa Kemal ve Milli Mücadele dönemine derin bir romantizmle yaklaşarak yoğun bir kutsallık atfetmesine ve mevcut olanı anlamak için sürekli bu kutsal ana dönmesine neden olmuştur. Öyle ki; İlhan, Türkiye solunun Kemalizm ve sosyalizm arasında kurduğu olumlu ilişkiyi onaylayan yaklaşımının ötesine geçerek, Türk sosyalizminin temelini Milli Mücadele ve Mustafa Kemal'de aramaya başlamıştır.

Kemalizm ve sosyalizm antiemperyalisttir ${ }^{87}$ diyen İlhan'ın, antiemperyalizmi bu iki kavramla ilişkilendirmesinin en önemli nedeni, antiemperyalizmi, bağımsızlığın mümkünlük koşulu olarak görmesidir. Bu durum söyleme, sosyalizm ve milliyetçiliğin en temel şartı "tam bağımsızlık"tır şeklinde yansımıştır: "Ulusal Türk sosyalizmin tabanı, Müdafaa-i Hukuk Kemalizmi olmak lazımdır: yani siyasette, iktisatta ve kültürde 'tam bağımsızlık'” ${ }^{88}$

“Ortada bir antiemperyalist kurtuluş savaşı, bir ulusal demokratik devrim vardır" 89 diyen Attila İlhan'ın düşüncesinde antiemperyalizmin Kema- 
lizm ile ilişkisinde iki referans ve buna bağlı olarak iki dönemselleştirme söz konusudur. Bunlardan birisi, "Anadolu İhtilali" olarak adlandırdığı ve siyasi bağımsızlığın kazanıldığı Kurtuluş Savaşı dönemini referans alan "Kuvayı Milliye" kavramıdır ve bu kavramı, antiemperyalist Milli Mücadele'nin ortaya çıkmasına sebep olan duygu olarak görmektedir. ${ }^{90}$ Diğeri ise "Anadolu inkılâbı" ya da" ulusal demokratik devrim" olarak adlandırdığı, Kemalizm’ in uygulanma yani tam bağımsız, antiemperyalist, laik ve demokratik Türkiye Cumhuriyeti'nin kurulması sürecini referans alan ve bazen bir önceki süreci de kapsayan "Müdafaa-i Hukuk" kavramıdır. ${ }^{91}$

İlhan, Kemalizm konusunda verilen tavizlerin Türkiye'yi yeni bir savaş durumu ile karşı karşıya getirdiğini ve Türkiye' nin antiemperyalist bir milliyetçiliği sahiplenerek Kurtuluş Savaşı'nda ortaya çıkan yirminci yüzyılın ilk "Halk Kurtuluş Ordusu" olarak adlandırdığ ${ }^{92}$ Kuvayı Milliye'nin ruhuna tekrar ihtiyaç duyulduğunu düşünmektedir..$^{93}$ Antiemperyalizme karşı milliyetçi bir tepki olarak “Kuvayı Milliye" kavramının, İlhan'ın Kemalizm ve dolayısıyla ulusal sosyalizm algısındaki yeri çok önemlidir. Milli Mücadele'nin silahlı/ askeri gücünü, ulusal kuvvetleri ifade eden kavrama, Mustafa Kemal'den bile daha fazla anlam yükleyen İlhan'ın "Kuvayı Milliye" kavramı bazen somut bir gerçekliği bazen romantik bir imgeyi işaret etmektedir. Kuvayı Milliye, İlhan için Cumhuriyet ve Kemalizm'e giden yolda Milli Mücadele'yi gerçekleştiren tüm toplum kesimlerinin birlikteliği olarak Müdafaa-i Hukuk'un ruhu ve yirminci yüzyılın ilk Halk Kurtuluş Ordusu'dur. ${ }^{94}$ Aynı zamanda Kuvayı Milliye, işçi, köylü ve yoksul Anadolu halkının işgale karşı direnişi ile oluşan milliyetçi bir tepki ve bu tepkinin harekete geçirdiği ulusal bilince sahip halk hareketidir. ${ }^{95}$ İlhan kendisi milliyetçi bir dişa vurum olan hareketin Türkçülük üzerinden örgütlendiğini şöyle anlatır:

Kuva-yı Milliye'yi ve Müdafaa-i Hukuk'u örgütleyenler Türkçülerdir. Onlar daha önce Türkçü hareketin içindedirler. (...) Türkçü ne demektir? Türkçü, Batı1 emperyalizme karşı ayağa kalkan ve ona karşı çıkan adam demektir. Türkçü, Türk kimliğini açığa çıkarıp, Batılının ona olan baskısına karşı koyan adam demektir. Türkçü, tam bağımsız ve özgür bir ülke olarak devam etmesini sağlayan adam demektir. ${ }^{96}$

Kemalizm'i sürdürülebilir kılmanın askeri, siyasi, ekonomik ve kültürel olarak emperyalizmle mücadeleye, bunu mümkün ve sürekli kılacak bir antiemperyalist platforma bağlı olduğunu savunan İlhan; bu platformu tanımlarken, savaş terminolojisini kullanarak, tüm vatanın tehlikede olduğunu ve topyekûn savaşın zorunluluğunu, savaşın komutanı Mustafa Kemal'in şu sözlerine atıf yaparak destekler: 
Bunun içindir ki, vatanı savunma ve korumadan ibaret olan asıl görev, doğrudan doğruya milletin kendisine yönelmiş oluyordu. Millet orduya, kendi içinden teslim ettiği fertlerini, düşman saldırısına uğrayan bölgelerin savunmasına, düşman saldırısına uğrayan kardeşlerinin hayatının savunmasına memur etmeye mecbur olmuştur. İşte buna Kuva-yı Milliye diyoruz, bütün kâinat da böyle diyor. ${ }^{97}$

\section{"Kuvayı Milliye"'den "Müdafaa-i Hukuk"a: Ulusal Demokratik Devrime}

İlhan'ın, 1960'larla birlikte antiemperyalist Milli Mücadele kavrayışı ile kullanmaya başladığı "Kuvayı Milliye" kavramının ilk ve tek savunucusu kendisi değildir. İlhan'ın, 1960'ta Varlık Dergisinde, 27 Mayıs konusundaki düşüncelerini dile getirmek için yazdığı bir şiirde rastlanan"8 "Kuvayı Milliye" kavramını, İlhan'dan daha önce dile getiren isimlerden birisi "Kuvayı Milliye" destanının da yazarı olan 1959'da Kuvayı milliye bayrağı altında ikinci kez toplanma çağrısı yapan Nazım Hikmet'tir. Bir diğer isim de "İkinci Kuvayı Milliye" olarak değerlendirdiği 27 Mayıs'ı kutlamak için Milli Birlik Komitesi'ne tebrik telgrafı çeken Hikmet Kıvılcımlıdır. ${ }^{99}$

İlhan “Kuvayı Milliye” kavramını, 1970'lerde emperyalizmin ulusal plandaki yansıması olarak gördüğü faşizme karşı "solda birlik" çağrısının felsefesi olarak kullanmıştır. ${ }^{100}$ Bu birlik çağrısının nedeni 1970’ler solunun Türkiye solunun içinde gözlemlediği çeşitlilik ve solun Kemalizm ile mesafesidir. ${ }^{101}$ Çünkü Türkiye solu döneme, görüş ayrılıkları temelinde farklı sosyalizm anlayışları ve devrim stratejileri ile oldukça dağınık girmiştir. ${ }^{102}$ Diğer taraftan, Kemalizm ile arasına mesafe koymaya başlayan Türkiye solu için Kemalizm, iktidar odağı olmaktan uzaklaşmaya başlamıştır. ${ }^{103}$ Yine bu dönemde, kitlesel desteğini artıran "sol" ile politik kimliği "görece katı ve görece militan bir politik üst kimlik" olarak tanımlayan "sağ" arasında kutuplaşma ve şiddet içeren çatışmalı bir sürece girilmiştir. ${ }^{104}$

$\mathrm{Bu}$ çatışmanın nedenini, emperyalizmin ulusal planda yansıması olarak faşizmin solu bitirme çabası olarak gören İlhan, "faşizm”i Türkiye'nin geri kalmasını isteyen "domuz" emperyalist sistem ve onun içerideki işbirlikçileridir ${ }^{105}$ diyerek emperyalizm üzerinden tanımladığından, asıl çatışmanın emperyalizm ile "Kuvayı Milliye” arasında geçtiğini düşünmektedir. ${ }^{106}$ İlhan'ın düşünce dünyasında bu kadar önemli bir yer işgal eden "Kuvayı Milliye” kavramı, zaman zaman yerini "Müdafaa-i Hukuk” kavramına bırakmaktadır. Bu yer değişikliği ya da "Müdafaa-i Hukuk" kavramının "Kuvayı Milliye" kavramının önüne geçmesi ulusal demokratik devrim kavrayışı ve buna bağlı 
olarak düşünce dünyasındaki iki yönelimle ilişkilendirilebilir. Bunlardan ilki, Kemalizm bağlamında, antiemperyalist Kurtuluş Savaşı'nı kazanan ve ulusal demokratik devrimde Mustafa Kemal ile birlikte yürüyen kul değil, birey olmak isteyen; taşralı veya muhafazakâr; Kürt, Çerkez, Laz ya da Müslüman tüm toplum kesimlerinin biraradalığına yapılan vurgudur. Bu vatandaşlık temelli bir milliyetçilik değerlendirmesiyle ulusal demokratik devrimi, "İkinci Fransız İhtilali" olarak algılamasıyla ilgilidir ve ulusal burjuvazi olmaması nedeniyle Türk milliyetçiliğinin sınıfsal tabandan yoksun olduğu sonucuna varır. ${ }^{107}$ Diğeri; sosyalizm bağlamında, sosyal sınıfların var olmadığ1 Kurtuluş Savaşı ve izleyen dönemde halk, eşraf, aydınlar ve bürokratlardan oluşan sınıfsız ve imtiyazsız bir topluluğun emperyalizm karşısında biraradalığına yapılan vurgudur. Bu, İlhan'ı burjuvazi ve işçi sınıfının oluşmadığı bir toplumda asıl çelişkinin emek-sermaye arasında değil, emperyalizm ile Türk halkı arasında olduğu sonucuna vardırmıştır. ${ }^{108}$ Bu sonuç ise, hem teorik hem de pratik olarak İlhan'ın ulusal sosyalizm kavrayışının sınırlarını olabildiğince genişletmiştir. Şöyle ki, kendi sınıfsal temeli olmayan Kemalist milliyetçiliğin emperyalizm karşısında homojenize ettiği tüm toplum kesimleri, sosyalizm açısından da sınıfsız ve imtiyazsız bir topluluk olarak İlhan'ın Türk sosyalizmi kavrayışının toplumsal tabanını oluşturmuştur.

Diğer taraftan, Türkiye'ye özgü koşullar üzerinden çelişkinin emek-sermaye çelişkisi olmadığı düşüncesi İlhan'ı Türkiye sosyalizmi için “Avrupalı bir bilim adamı olarak Avrupa merkezci düşünen ve mazlum milletlerle Batı emperyalizmi arasındaki karşıtlığı hafife alan Marks" ${ }^{109}$ dışında bir teorik çerçeve aramaya itmiştir. Bu çerçeve, Tatar Müslüman sosyalist Sultan Galiyev ve "Mazlum Milletler" kuramıdır. ${ }^{110}$ Çünkü İlhan'a göre, Galiyev'in “devrim mutlaka Mazlum ülkelerden yani sömürge ve yarı/Sömürge durumuna indirgenmiş Doğu ülkelerinden gelecektir" tespiti ${ }^{111}$, Avrupa sosyalist teorisinin yanıldığını göstermiş ve sınıf yerine millet kavramını merkeze alan bir sosyalizmi mümkün hale getirmiştir. ${ }^{112}$ Galiyev İlhan için Batı dışı bir toplum olarak Türkiye'ye özgü sosyalizm kavrayışının teorik çerçevesini oluşturmuştur. ${ }^{113}$ Bunun yanı sıra İlhan, Galiyev'in Mustafa Kemal ile benzer ve hatta ilişki içerisinde olduğu savunarak ${ }^{114}$ Anadolu İhtilali'ni Galiyev üzerinden bir adım daha sosyalizme yaklaştırmıştır.

Attila İlhan, ulusal demokratik devrim dolayımıyla Galiyev'i ve tezlerini yoğun bir şekilde solun gündemine getirirken, aynı zamanda Türkiye solunda oldukça uzun soluklu bir tartışmanın da tarafı olmuştur. Türkiye solunda 1960'larla sosyalizme ulaşmanın stratejisi bağlamında başlayan ve temelde 
Türkiye' nin önündeki aşamanın demokratik devrim mi, sosyalist devrim mi olduğu üzerinden süren tartışma, $\mathrm{MDD}^{115}$ ve sosyalist devrim mi sorusunun cevabını aramaktadır. ${ }^{116}$ MDD yerine "ulusal demokratik devrim" ifadesini benimseyerek söylem olarak MMD hareketi ile mesafeli gibi görünse de, antiemperyalist mücadeleyi öncelediği ve sosyalist mücadelenin bugünün işi olmadığını hatta ulusal demokratik devrimin sosyalizm değil demokrasi amaçladığını ${ }^{117}$ düşündüğü için, İlhan'ın sosyalist mücadele yanlısı olmadı̆̆ı söylenebilir.

Diğer taraftan İlhan'ın demokrasinin içselleşmesinden sonra sosyalizme geçişle ilgili belirginleşmiş ve uzun soluklu tartıştığı bir önerisi yoktur ve “İkinci Fransız İhtilali" olarak gördüğü ve "Anadolu İnkılabı" olarak adlandırdığı Kemalist devrimi, çoğunlukla sosyalist literatür açısından değil, burjuva demokratik devrim literatürü açısından değerlendirmektedir. Bir başka ifadeyle İlhan kavramı, Türkiye solunda ifade edildiği şekliyle bir toplumun sosyalist devrim eşiğine varabilmesi için bağımsız ve demokratik bir toplum olması, yani Milli Demokratik devrimin bütün görevlerini yerine getirmiş olması kapsamında ${ }^{118}$ ya da Türkiye'nin olası bir sosyalizm deneyiminde bir aşama olarak görmez. Bunun yerine, imparatorluktan millete ve padişah iradesinden Cumhuriyete geçiş şeklinde ulus-devlet kurma ve rejim değişikliği kavramları etrafında bir bütünsellik olarak ele alır. ${ }^{119}$

Fakat yine de Milli Mücadele sonrası bağımsızlığın devam etmiş olması halinde tarihsel olarak bir sosyalizm gerçeği ile karşı karşıya gelinebileceğini de kaçırılmış bir fırsat imasıyla belirtir. "Belki Türk ekonomisi yeniden emperyalist sistemin denetimine verilmemiş olsaydı, ulusal burjuvazi sanayileşme atılımını çoktan gerçekleştirecek, bu arada sağlıklı yoldan oluşmuş proletarya, sosyalizmi tarihsel olarak ve sapasağlam gündeme getirecekti" 120 demektedir.

İlhan, ulusal demokratik devrimin antiemperyalist ve antikapitalist olduğunu savunmaktadır. ${ }^{121}$ Diğer taraftan Milli Mücadele dönemi sosyalistleri olarak gördüğü Türkiye Komünist Fırkası üyelerinin ve de daha sonra halkçılık programının temeli olacağını söylediği fırka beyannamesinin de düşmanı dışarıda emperyalizm, içeride kapitalizm olarak tanımladıklarını da belirtmektedir. ${ }^{122}$ Bunlara rağmen İlhan'ın düşüncesinde bütünsel ve doğrudan bir kapitalizm karşıtlığ1 yoktur ve kapitalizm konusundaki düşünceleri değişiklik arz etmektedir. Şöyle ki, İlhan temelde Mustafa Kemal'in antiemperyalist bir mücadelenin ardından "ulusal kapitalizm" kurma amacı taşıdığını ve bunun da ulusal kalkınmanın temeli olduğunu düşünmektedir. İlhan'a göre, 
"Mustafa Kemal ulusal demokratik bir devrim yaptı, bu devrimin sinıfsal tabanı ulusal burjuvazidir, onun içindir ki, Anadolu İhtilali bir yandan ulusal burjuvazi yaratmak peşine düşmüş, bir yandan 'Atatürk Devrimleriyle' kültürel ortamı feodal ümmet üstyapısından arındırmaya çabalamıştır." ${ }^{123}$ Fakat İlhan'a göre, adına devrim yapılan sınıf olmadığından Mustafa Kemal'in ilk işi, ulusal kapitalizmin kurulabilmesi için ulusal burjuvazinin yaratılmasıdır. Çünkü İlhan'a göre, Mustafa Kemal, kapitalizmin yerli ve ulusal olanına değil, yabancı olanına karşıdır. ${ }^{124}$ Diğer taraftan ulusal burjuvazi oluşturma çabasının da, devrimin kendisi gibi İnönü döneminde bürokrasinin burjuvaziyi denetim altına alınma çabasıyla bozulduğunuiddia eder. ${ }^{125}$

\section{Kemalizm'e Bağlılığı Ölçüsünde Anayasal Bir Sosyalizm}

Ulusal Türk sosyalizminin, özgürlükleri hesaba katarak özgürlükçü ve anayasal bir platformda kurulması gerektiğini savunan İlhan'ın anayasal sosyalizm vurgusu; biri Kemalizm, diğeri Türkiye solu ile ilgili iki konuya ilişkindir. İlhan, anayasal sosyalizmin Kemalizm'e ve onu koruyan yasalara bağlılığı ifade ettiğini belirtmektedir. ${ }^{126} \mathrm{Bu}$, İlhan'ın sosyalizm düşüncesinin sınırlarında Kemalizm olduğunun tekrar dile getirilişidir. İkincisi ise, Türkiye soluna ilişkin 1960'lardan itibaren var olmaya başlayan "devrimci şiddet" eleştirisi ${ }^{127}$ ve kendisini Türkiye solundan ayırma çabasıdır. İlhan, "askeri müdahale yoluyla devrim gerçekleştirme yanlısı" olarak nitelendirdiği sol yönelimlerin, Türkiye solunun yeterince halk desteği görmesini engellediğini düşünmektedir:

Bazıları ise 60'lı yıllardan itibaren kısmen Maozedun/Krusçof uyuşmazlığından, kısmen Küba'daki Castro/Gucvcra 'romantizminden' etkilenerek, 'silahlı eylem' açmazına girer; (...) Hazin olan bu devrimciliklerin, halka derinlemesine intikal etmekte olan Türkiye İşçi Partisi'nin önce duraklamasına, sonra da sarsılmasına sebep olmasıydı; ayrıca bunlar da, en az 'tepeden inmecilik' kadar provokasyona açı ve elverişli görünüyordu. ${ }^{128}$

İlhan, 1960'ların sonlarına doğru Türkiye solunun gittikçe farklılaşarak bölündüğünü, parlamenter siyasetin zayıfladığını, halkın yerine silahlı mücadeleye yönelen gençlerin desteğini alır hale geldiğini ve "marjinalleştiğini” düşünmektedir. ${ }^{129}$ Türkiye' deki devrimci mücadelenin öncülüğünü “zinde güçler"'e vererek ${ }^{130}$, gençleri sosyalist mücadelenin önemli unsuru olarak gören, Çin ve Küba deneyimlerinin yasalara uygun olduğunu savunan Yön Hareketi ${ }^{131}$ İlhan'ın en fazla eleştirdiği gruptur. ${ }^{132}$ İlhan sosyalist bir partinin varlık koşuluna olan inancına ve hatta TİP'in başarısına inanmasına rağmen, meşru ve legal bir platformda kalacağını beyan eden TíP' ${ }^{133}$ değil, merke- 
ze yakın seçmenlerden oy alma çabasında ve aşırı sola kapalı olan CHP'yi ${ }^{134}$ desteklemiş̧ir. İlhan bu desteğinin nedenini anayasal bir platformda "insanca ve hakça bir düzen" değişikliği beklentisi olarak açıklasa ${ }^{135}$ da bu desteğin nedeni, Kemalizm'e en yakın, Kemalist kanunlarla en uyumlu ve kendisini Atatürk'ün partisi olarak görmesidir.

İlhan, toplumsal bir dönüşüm tasarımı olan sosyalizmin toplumsal düzenin toptan değişimini barındırdığını kabul etmektedir. Fakat Türkiye'de toptan bir dönüşüm için şartların olgunlaşmadığını, bir başka ifadeyle toplumsal sınıfların yeterince gelişmediğini Engels' in "bilinçsiz kitlelerin başındaki küçük azınlıkların iktidarı aniden ele geçirmesiyle başarılan devrimlerin devri geçmiştir" sözü ile açıklar. ${ }^{136}$ Ayrıca bunun devrimci ulusal serveti israf ederek baba parası yiyen asalaklar olarak gençlerin başaracağını düşünmek İlhan'a göre gaflet ve ihtirastır. ${ }^{137}$ Diğer taraftan İlhan, yeterince bilinçli olmayan işçilerin de anayasal Türkiye sosyalizminin itici gücü olmayacağını düşünmektedir. ${ }^{138} \mathrm{Bu}$, İlhan'ın Türk sosyalizmini iş̧̧i sınıfı değil; iş̧̧i, köylü, küçük memur, küçük aydın, yoksul kentliden oluşan geniş bir "halk cephesi"139 tahayyülü ile karşı karşıya bırakmıştır.

\section{Sonuç}

Başlangıçta kendini önceleyen sol aydınların aydınlanma, Batılılaşma ve kalkınma konusundaki düşüncelerini edebiyat ve sanat konulu yazılarıyla onaylayan Attila İlhan, Türkiye solunun Kemalizm ile sosyalizm arasındaki bağın sorunsallığını kabul ettiği dönemde adeta onların yarım bıraktığını tamamlamak istercesine Türkiye'nin kendine özgü bir sosyalist modelinin kurulabileceğini savunmuştur. 1970'leri, "ipe sapa gelmez komünist eylem enflasyonu" ortamında geçirdikten ${ }^{140}$ ve "solda birlik" üzerinden tahayyül ettiği uzlaşının gerçekleşmediğini gördükten sonra, Türkiye solu için bir varlığın muhafaza edilmesi olarak da kabul edilebilecek 1980'leri Osmanl, İslam ve Türk kavramları üzerinden birlik çağrısı ile geçirmiştir. Ulusal olanın karşısındaki tehdidi küresel olan olarak belirlediği 1990'larda ise, küreselleşmenin yayılmacılığına karşı Misak-ı Milli ile sınırlı antiemperyalist kurtuluşçu milliyetçilikten, Misak-ı Milli sınırları dışına taşan ve Türkiye'nin dışındaki Türk ve Müslüman toplulukları kapsayacak şekilde yayılmacı ve tahakkümü amaçlayan bir milliyetçiliğg ${ }^{141}$ kaymıştır. Orta Asya Türkleri ile vatan ve etnisite (Türklük) üzerinden; Balkanlar ve Arap Yarımadası'ndaki Türk ve Müslümanlar ile vatan ve din (İslamiyet) üzerinden bir akrabalık kuran İlhan, Osmanlı İmparatorluğu'nun hâkimiyet alanında bir birlik tahayyül etmiştir. Emperyalizm/küreselleşme karşısında oluşacak bu birliğe, "Devin uyanı- 
Ş1" adını veren İlhan ${ }^{142}$, “dünya bize düşman" ortak kabulü üzerinden ${ }^{143}$ bir tür mazlum millet dayanışması önermiştir. ${ }^{144}$ Türkiye solunun gündeminde ulus-devletin çözülmesi tehlikesi kapsamında 2000'lerle birlikte tekrar belirginleşen emperyalist tehdit; İlhan'ın "solcu olmayı" yine antiemperyalizmle bağlantılı olarak, Amerikan sevmezlik ve NATO karşıtlığ ${ }^{145}$ üzerinden tanımlamasına ve ortak düşmana karşı "milleti uyandırma" çabasına girmesine neden olmuştur. Tüm bu süreçte savunduğu ulusal sosyalizm düşüncesinin temel referansı Kemalizm olan İlhan'ın, Türkiye solu içindeki özgünlüğü için ise şunlar söylenebilir:

Öncelikle, ulusal kültür sentezi ve ulusal sosyalizm kavrayışının merkezinde Kemalizm olan İlhan, toplumsala ait olan her şeyi Kemalizm bağlamında tartışarak, Kemalizm'den hiç uzaklaşmamış, aksine Kemalizm’i sürekli canlı tutarak, her dönem için Türkiye'ye özgülügüun Kemalizm olduğuna inanmış ve bunu savunmuştur. Bu savunu, Türkiye'de Kemalizm'in temin edilmesi ile sosyalizmin de kendiliğinden ortaya çıkacağı düşüncesini sabitlemiştir. İlhan bu bakış açısıyla "ulusalcılık" olarak kavramsallaşan ulusal sol/ sosyalizm düşüncesinin toplumsal kabul görmesi ve yaygın kitlelerin dikkatini çekmesine aracılık eden şahsiyetlerden birisi olmuştur. Diğer taraftan da Kemalizm'in düşünce dünyasındaki önemine bağlı olarak, Türkiye solunun Kemalizm ile arasına mesafe koyamama durumunun izlendiği uğraklardan birisi olmuştur.

İkincisi, Türkiye'nin ekonomik ve siyasal olduğu kadar, kültürel olarak da emperyalizmin tuzağında olma durumuna bir tepki olarak milliyetçiliğinin kültürel boyutunun da siyasal ve ekonomik boyutu kadar, hatta onlardan daha fazla öne çıkmasıdır. Ulusal kültür sentezi, eski kültürün yeni içinde temsilini içeren İlhan'ın düşüncesinde Osmanl1-Doğu-Müslüman kültürünün ulusal sentez içindeki önemi oldukça hayatidir. "Müslüman geçmişi ve görenekleriyle barışmış laik Türkiye" savunusư ${ }^{146}$, laiklik karşıtlığı şeklinde okunabilmiştir.

Son olarak, bu çalışmanın temel argümanlarından da birisi olan, Türkiye solunun Kemalist kadro ve Kemalizm ile kurduğu olumlu ilişki, solun dönem dönem Milli Mücadele ve Kemalist devrime dönmesini ve toplumu bu kavramlar etrafında bir araya getirme çabasını meşrulaştırmıştır. Fakat bu çabanın en uzun soluklu olarak izlendiği kişi, Attila İlhan'dır. İlhan'ın bu çabası, onu Milli Mücadele dönemini sürekli yaşamasına/yaşatmasına ve bu dönemin Mustafa Kemal önderliğinde bir sosyalist deneyim olarak bile okunmasının mümkün olduğuna inandırmıştır. 


\section{Notlar}

1 Murat Belge'nin “icraya karşı (çeşitli) fren sistemleri oluşturan” olarak tanımladığı 1961 Anayasası'nın kuşkusuz ki bu ortamın oluşmasının en önemli faktörü olduğu söylenebilir. Ayrıca bkz. Murat Belge, "Marksizmin "Millileşmesi" mi, "Yerlileşmesi" mi?," Modern Türkiye'de Siyasi Düşünce Cilt 8: Sol içinde, der. Tanıl Bora, Murat Gültekingil (İstanbul: İletişim, 2007), 33. Fakat 1960'ların demokrasi açısından sınırsız bir iyilik hali barındırdığını da söylemek doğru olmayabilir. 1963 yılında kurulmaya başlanan Komünizmle Mücadele Derneklerinin sayısının yüz elliye ulaşması ve dönemin Cumhurbaşkanının bu derneklerin “Fahri Genel Başkanı" olması dönemin genel havasını, Türkiye' de yürütülen anti-komünist mücadelenin taraflarını ve psikolojisini anlamak bakımından önemlidir. Devletin en tepesinin himayesindeki bu mücadelenin devletin radyosu aracıllğıyla da sürdürülmesi mücadelenin yaygınlığı açısından fikir verebilir. Çünkü devlet radyosundan, "Komünizm tatlı dille arkadan sokan bir yılandır" veya "Komünist, Türk ve Müslüman kıyafetine bürünerek arana girer" anonsları yapılmaktadır. Ayrıca bkz. Yalçın Küçük, Türkiye Üzerine Tezler-I (19081978), (İstanbul: Tekin, 1984), 549-552.

2 Yön hareketi, 1042 kişinin altına imza attığı Yön Bildirisi ve 27 Mayıs darbesinin ardından sosyalist bir söylemle haftalık fikir ve sanat gazetesi olarak 20 Aralık 1961'de yayın hayatına başlayan ve aynı adı taşıyan Yön dergisi ile beliren bir siyasal harekettir. Ayrıca bkz. Gökhan Atılgan, "Yön Devrim Hareketi," Modern Türkiye'de Siyasi Düşünce Cilt 8: Sol içinde, der. Tanıl Bora, Murat Gültekingil (İstanbul: İletişim, 2007), 599-600. Sendikacılar tarafından kurulan ve üyelerinin yarısına yakınının çalışanlardan oluştuğu Türkiye İşçi Partisi, 1965 seçimlerindeki başarısı da dikkate alındığında Türkiye siyasal hayatındaki en önemli unsurlardan birisi olmuştur. Ayrıca bkz. Ergun Aydınoğlu, Türkiye Solu (1960-1980) (İstanbul: Versus, 2008), 102.

3 Murat Belge, "Milliyetçilik ve Sol," Birikim 165 (2003): 27-30.

4 Attila İlhan, Hangi Batı (İstanbul: İş Bankası Kültür Yayınları, 2005), 286.

5 Attila İlhan, edebiyatla ilgilenen bir ailenin çocuğu olarak 1925'te İzmir'de doğar. Küçük yaşta edebiyata ilgi duyan İlhan oldukça genç bir yaşta edebiyat dünyasına adım atarak edebiyat dünyasının önemli şahsiyetlerinden birisi olur. Ayrıca bkz. Selim İleri, Nam-ı Diğer Kaptan - Attila İlhan'ı Dinledim (İstanbul: İş Bankası Kültür Yayınları, 2005), 8-34. Çocukluk yılları Cumhuriyet'in kuruluş yıllarına, gençlik yılları İkinci Dünya Savaşı yıllarına denk gelen İlhan, yakın dönem Türkiye tarihine uzun süre tanıklık eden şahsiyetlerden birisidir.

6 Attila İlhan, Gerçekçilik Savaşı (İstanbul: İş Bankası Kültür Yayınları, 2004), 299.

7 Attila İlhan, on altı yaşında bir lise öğrencisiyken kız arkadaşına yazdığı (1941) Nazım Hikmet şiirleri nedeniyle dört ay kaldığı cezaevinde Türkiye Komünist Partisi (TKP) üyeleri aracllığıyla sosyalizm ve komünizmle tanışır. Okuldan uzaklaştırılır ve kendisine Türkiye'nin hiçbir yerinde okuyamayacağına dair bir belge verilir. Ayrıca bkz. Zeynep Aliye, Mavi Adam - Attila İlhan'la Söyleşi (Ankara: Bilgi, 2001),17. İlhan, iki y1l süren hukuk mücadelesinin ardından tekrar okuma hakkını elde ederek liseyi bitirir ve İstanbul Hukuk Fakültesi'ne kaydolur. Yasaların komünist ilan ettiği İlhan'ın sosyalizmle ilişkisi, Nazım Hikmet hayranlığı ile sınırlıdır. Ayrıca bkz. Attila İlhan, Hangi Sol (İstanbul: İş Bankası Kültür Yayınları, 2008), 
52. Sürekli kovuşturma ve polis baskısının verdiği sıkıntı ile Türkiye'den ayrılmaya karar veren İlhan, 1949 yılının sonbaharında Fransa'ya gider. Ayrıca bkz. İleri, Nam-ı, 100.

8 Aliye, Mavi, 99.

9 Attila İlhan, Abbas Yolcu (İstanbul: İş Bankası Kültür Yayınları, 2004), 165.

10 İleri, Nam-ı, 128.

11 TSP, 28 Ağustos 1950' de tekrar kurulunca yayın organı Gerçek gazetesi de 28 Eylül -18 Aralık 1950 arasında tekrar yayınlanmıştır. Gazetede roman tefrikaları, şiirleri ve Marksizm üzerine yazıları yazan İlhan, partide de aktif olarak görev almıştır. Ayrıca bkz. Emin Karaca, Unutulmuş Sosyalist: Esat Adil (İstanbul: Belge, 2008), 298.

12 İlhan'ın, ikinci seyahati Nazım Hikmet yurtdışına çıktıktan (Haziran 1951) sonra ve 26 Ekim 1951'de başlayan "Komünist tevkifatı" ndan öncedir. Ayrıca bkz. İleri, Nam-l, 154. Bu tarihler bir arada düşünüldüğünde İlhan'ın ikinci Fransa seyahatini 1951 yılının Temmuz-Eylül ayları arasında gerçekleştirdiği düşünülebilir.

13 Attila İlhan ilk Fransa seyahatinin amacını açılarken olduğu gibi, Fransa'da geçirdiği süreyi ve hatta Türkiye'ye dönüşünü “Nazım Hikmet'i kurtarma” temasıyla özdeşleştirir. Fakat Fransa'da Nazım Hikmet'in hapisten çıarılması için uluslararası bir kampanya yürüten İleri Jön Türk Birliği üyesi Fahri Petekkaya, İlhan'ın bu süreçte aktif olarak yer almadığını, "o taraklarda bezi yoktu" ifadesi ile özetler. Ayrıca İlhan'ı içinde olmadığı bir mücadeleyi sahiplendiği için "hiç kimse başkalarının mücadelesini sahiplenmemeli" diye eleştirir. Ayrıca bkz. M. Şehmus Güzel, Fahri Petek: Bir Hayat, Üç Can (İstanbul: Sarı Defter, 2009), 199. Diğer taraftan Nazım Hikmet'in kurtarılması amacıyla İstanbul Yüksek Tahsil Gençlik Derneği 15 Mayıs 1950'de Çiçek Palas'ta bir toplantı düzenlenmiştir. İlhan kendisinin de içinde olduğu bir grubun organize ettiğini söylediği toplantıyı, "vaziyetin kötü gideceğini anlayarak" açış konuşmasının ardından terk etmiş ve toplantı polis baskınına uğramıştır Bu olaydan çok geçmeden Nazım Hikmet Temmuz 1950'de hapisten çıar, fakat İlhan kendisiyle görüşmemiştir. Ardından Haziran 1951'de yurtdışına çıkan Nazım Hikmet'in kendisine haber gönderdiğini iddia ederek, ikinci Fransa seyahatini de Nazım Hikmet'le ilişkilendirir. Ayrıca bkz. İleri, Nam-l, 137-146.

14 Hasan Bülent Kahraman, “Türk Solunun Çıkmaz Sokağı: Kemalizm (Ordu) İlişkisi," Doğu Batı 59 (2011): 50.

15 Zeynep Ankara, Yalnız Şövalye Attila İlhan (Ankara: Bilgi, 1996), 33.

16 Attila İlhan, Hangi Atatürk (İstanbul: İşs Bankası Kültür Yayınları, 2004), 39.

17 İlhan, Hangi, 99-100.

18 İlhan, Abbas, 176.

19 İlhan, Gerçekçilik, 9-11.

20 Attila İlhan, “Kemalist Aydının Sorumluluğu," Pazar Postası 78 (1952): 2.

21 İlhan, Gerçekçilik, 60-61.

22 İlhan, öncelikle kavramın Stalin dönemi "sosyalist gerçekçilik" yaklaşımdan tamamen farklı olduğunu söyler. Ayrıca bkz. İlhan, Hangi, 9. Bunun nedeni ise, Sosyalist gerçekçilerin sos- 
yalizme değil Marksizm'in Leninist yorumuna dayanan komünist ve partici bir sanat yolu benimsemeleri ve sosyalist gerçekçiliğin de toplum düzenini komünizmin metotları ve parti emirleri doğrultusunda yorumlama ve değiştirme çabasıdır. Ayrıca bkz. Attila İlhan, "Osman Mazlum'a karşı Ömer Haybo," Pazar Postası 45 (1957): 7.

23 Sol kesimden kişiler İlhan'ı "Moskof düşmanı", teorisini de milliyetçi olarak değerlendirirken, muhafazakâr düşünceye sahip kişiler ise "Moskof ajanı", teorisini de Rusya'nın resmi sanat anlayışı olarak nitelendirmiştir. Ayrıca bkz. Belgin Sarmaşık, Attila İlhan: "Açtırma Kutuyu!.." - Röportajlar-I (1946-1983) (Ankara: Bilgi, 2005), 45; Ahmet Oktay, "Attila İlhan: İmkânsızı Zorlamak," Doğu Batı 35 (2006): 109-115; Mahmut Babacan, “Dönemler, Yönelimler ve Eleştiriler Çerçevesinde Attila İlhan şiiri," Attila İlhan içinde, der. Yakup Çelik (Ankara: Kültür Bakanlığı, 2006), 194-211.

24 Belgin Sarmaşık, Attila İlhan: Söyletme Kötüyü!.. - Röportajlar-II (1983-1987) (Ankara: Bilgi, 2005), 90.

25 Attila İlhan'ın üçüncü ve son Fransa seyahatinin tarihleriyle ilgili oldukça farklı bilgiler mevcuttur. İlhan bir çok röportajda bizzat kendisi 1960'da gittiğini söylemektedir. Fakat İlhan, Türkiye İşçi Partisi kurma heyetinin davetlisi olarak katıldığı toplantının basılmasını Fransa'ya gitme fikrini pekiştirdiğini söyler. İlhan'ın bahsettiği toplantının 11 Kasım 1962' de Mehmet Ali Aybar'ın düzenlediği Beyaz Saray adını alan toplantı olması ihtimali çok yüksektir. Çünkü Illhan'ın dediği gibi TiP tarafından düzenlenen ve karşıt görüşlü kişilerin bastığı toplantı, bu toplantıdır. Ayrıca bkz. Şükran Kurdakul, Cezaevinden Babıali'ye Babıali'den TiP'e - Anılar (İstanbul: Evrensel, 2003), 93-113. Dolayısıyla İlhan'ın son Fransa seyahatini 1963 başlarında gerçekleştiği söylenebilir.

26 İleri, Nam-l, 214.

27 Öncelikle, içindeki yazılar daha erken tarihli olmasına rağmen Hangi Batı, Anılar ve Acılar dizisinin ikinci kitabıdır. Aynı dizinin ilk kitabı, İlhan'ın 1965-70 arasında kaleme aldığ1 yazılardan oluşan ve 1970'te basılan Hangi Sol kitabıdır. Hangi Batı kitabının ilk baskısında, İlhan'ın Paris'te yazdığı yirmi yazı yer almaktadır. Kitabın daha sonraki baskılarına İlhan'ın 1970'lerden sonra aynı konuda yazdığı yazılar da eklenmiştir.

28 İlhan, Hangi Batl, 124-125.

29 İlhan, Hangi Batı, 26.

30 İlhan, Hangi Batı, 92.

31 İleri, Nam-ı, 105.

32 İlhan, Gerçekçilik, 81.

33 İlhan, Hangi Atatürk, 157.

34 Attila İlhan, Bir Sap Kırmızı Karanfil (İstanbul: İşs Bankası Kültür Yayınları, 2005), 101.

35 İlhan, bu öğrenme süreci için: “Diyalektiğin ne demek olduğunu en azından on kişiye sordum Türkiye'de; kimse anlatamadı. Fransa'ya gittim. İşçi Üniversitesinde "Camarade" Paul (Paul arkadaş) Renault'ta işçiydi, o bana ayaküstü anlattı" ifadesini kullanmıştır. Ayrıca bkz. Attila İlhan, Sultan Galiyef: Avrasya'da Dolaşan Hayalet (İstanbul: İş Bankası Kültür Yayınları, 2005), 76 . 
40 İlhan, Hangi Sol, 218.

41 Attila İlhan, Hangi Sağ (İstanbul: İş Bankası Kültür Yayınları, 2005), 156.

42 Varlık yayınlarından 1970 yılında çıkan Hangi Sol adlı kitabının ilk baskısında İlhan, 1965-70 yılları arasında yazdığı on dokuz yazıyla sosyalizm konusunu tartısmaya açmıştır. İlhan burada birkaç anı ve Türkiye Sosyalist Partisi'ne bir değini dışında sosyalizmin Sovyetler Birliği ve Avrupa ülkelerindeki uygulamalarını eleştirmektedir. Kitabın daha sonraki baskılarına İlhan'ın sosyalizm konusunda 1970-75 yılları arasında yazdığı ve Türkiye'ye ilişkin tespit ve önerilerinin olduğu yazılar eklenmiştir.

43 İlhan, Hangi Sol, 66.

44 Özgür Gökmen, "Esat Adil Müstecaphığlu," Modern Türkiye'de Siyasi Düşünce Cilt 8: Sol içinde, der. Tanıl Bora, Murat Gültekingil (İstanbul: İletişim, 2007), 944.

45 İlhan, Hangi Atatürk, 422.

46 İlhan, Hangi Sol, 84.

47 Aliye, Mavi, 175-176.

48 Tanımlama, Murat Belge'ye ait. Ayrıca bkz. Belge, Marksizmin, 105.

49 Aliye, Mavi, 172.

50 İlhan, Bir, 100.

51 İlhan, Hangi Atatürk, 87.

52 Doğan Avcıŏlu, "Sosyalizm Anlayışımız," Yön 36 (1962): 3.

53 Muzaffer Karan, “Kemalizm Türk Sosyalizmi,” Yön 39 (1962): 7.

54 Attila İlhan, “Attila İlhan'ın Defteri,” Yön 189 (1966): 16.

55 Türkkaya Ataöv, “Türk Sosyalizmine Doğru,” Yön 12 (1962): 14.

56 Uğur Mumcu, “Türk Sosyalizmi,” Cumhuriyet (1962).

57 Mustafa Şener, “Türkiye İşçi Partisi,” Modern Türkiye'de Siyasi Düşünce Cilt 8: Sol içinde, der. Tanıl Bora, Murat Gültekingil (İstanbul: İletişim, 2007), 370.

58 Aydınoğlu, Türkiye, 175.

59 Mihri Belli, Milli Demokratik Devrim (Ankara: Aydınlık, 1970), 19.

60 Mehmet Ali Aybar, Bağımsızlık Demokrasi Sosyalizm (Seçmeler: 1945-1967) (İstanbul: Gerçek, 1968), 480. 
61 Sadun Aren, “Nasıl Bir Sosyalizm?,” Yön 12 (1962): 12.

62 Muzaffer Erdost, “Türkiye Sosyalizmi ve Sosyalizm,” Türk Solu 43 (1968): 5.

63 Attila İlhan, Faşizmin Ayak Sesleri (İstanbul: İş Bankası Kültür Yayınları, 2005), 140-141.

64 İlhan, Faşizmin, 105.

65 Doğan Avcıŏlu, Türkiye'nin Düzeni: Dün Bugün Yarın, (İstanbul: Tekin, 1995), 956.

66 İlhan Selçuk, “Milliyetçiliğin Temelleri,” Yön 96 (1965): 3.

67 Doğan Avcıoğlu, “Sosyalist Gerçekçilik,” Yön 39 (1962 ): 20.

68 Murat Belge, "Türkiye'de Sosyalizm Tarihinin Ana Çizgileri,” Modern Türkiye'de Siyasi Düşünce Cilt 8: Sol içinde, der. Tanıl Bora, Murat Gültekingil (İstanbul: İletişim, 2007), 37.

69 Ömer Laçiner, “Sosyalizm Versus Milliyetçilik,” Birikim 249 (2010): 65.

70 Suavi Aydın, "Türkiye Solunda Özgücülük ve Milliyetçilik," Modern Türkiye'de Siyasi Düşünce Cilt 4: Milliyetçilik içinde, der. Murat Belge (İstanbul: İletişim, 2007), 543-577.

71 Kavram Marksist literatürde geri kalmış ülkelerin emperyalist ülkelere karşı siyasi ve ekonomik tavrını ifade etmek için kullanılmaktadır. Ayrıca bkz. Tom B. Bottomer, Marksist Düşünce Sözlüğ̈̈̈, çev. Mete Tunçay (İstanbul: İletişim, 2005), 198.

72 Mete Tunçay, Türkiye'de Sol Akımlar (İstanbul: İletişim, 2009), 341.

73 Antiemperyalizm, Osmanlı İmparatorluğu'nun son dönemlerinde batı karşıtlığı olarak ortaya çıkmıştır. Ayrıca bkz. Şükrü Hanioğlu, "İttihatçılık," Modern Türkiye'de Siyasi Düşünce cilt 9: Dönemler ve Zihniyetler içinde, der. Murat Belge (İstanbul: İletişim, 2009) 256. Süreç içinde Batı düşmanlığına dönüşen antiemperyalizm, Birinci Dünya Savaşı işgalleri karşısında milliyetçilik bağlamında devam etmiştir. Ayrıca bkz. Şerif Mardin, Yeni Osmanlı Düşüncesinin Doğuşu (İstanbul: İletişim, 2009), 212.

74 İleri, Nam-1, 257.

75 Eric Hobsbawm, 1780'den Günümüze Milletler ve Milliyetçilik: Program, Mit, Gerçeklik, çev. Osman Akınbay (İstanbul: Ayrıntı, 1993), 176.

76 Attila İlhan, Hangi Edebiyat (İstanbul: Bilgi, 1993), 266.

77 Attila İlhan, Dönek Bereketi - Cumhuriyet Söyleşileri (İstanbul: İş Bankası Kültür Yayınları, 2005), 67-68

78 Suavi Aydın, Türkiye, 544.

79 Avcıŏlu, “Sosyalist," 20.

80 Doğan Avcıoğlu, “Milliyetçilere Sesleniş," Yön 78 (1963): 3.

81 Fethi Naci, "Bağımsızlıktan Yarı Sömürgeliğe," Ant 13 (1967): 7.

82 İlhan, Hangi Atatürk, 71.

83 İlhan, Hangi Batı, 302. 
84 İlhan, Dönek, 52.

85 İlhan, Sultan, 26.

86 İlhan, Faşizmin, 14.

87 İlhan, Bir Sap, 16.

88 İlhan, Bir Sap, 16.

89 İlhan, Bir, 28.

90 Attila İlhan, Ulusal Kültür Savaşı (İstanbul: İş Bankası Kültür Yayınları, 2005), 15.

91 İlhan, Bir, 204.

92 İlhan, Ulusal, 14.

93 İlhan, Ulusal, 15.

94 İlhan, Sultan, 15.

95 İlhan, Hangi Atatürk, 34.

96 İlhan, Hangi Atatürk, 370.

97 İlhan, Sultan, 270.

98 Attila İlhan, "Yarının Başlangıcı," Varlık 528 (1960): 9.

99 Aydınoğlu, Türkiye, 64-65.

100 İlhan, Faşizmin, 56.

101 İlhan, Faşizmin, 276.

102 Ömer Laçiner, “THKPC Bir Mecranın Başlangıc1,” Toplum ve Bilim 78 (1998): 7-21.

103 Ahmet İnsel, "Sosyalist Olduğum İçin Anti-Kemalist'im," Sol Kemalizme Bakıyor içinde, der. Levent Cinemre, Ruşen Çakır (İstanbul: Metis, 1991), 193-207.

104 Tanil Bora , “Süleyman Demirel," Modern Türkiye'de Siyasi Düşünce Cilt 9: Dönemler ve Zihniyetler içinde, der. Murat Belge (İstanbul: İletişim, 2007), 502-514.

105 İlhan, Bir, 138.

106 İlhan, Faşizmin, 99.

107 Illhan, Hangi Atatürk, 23.

108 İlhan, Hangi Atatürk, 307.

109 İlhan, Bir, 98.

110 İlhan, Hangi Atatürk, 315.

111 İlhan, Yıldız, Hilal ve Kalpak - Gazi'nin Ulusal Solculuğu, Cumhuriyet Söyleşileri (Ekim' 98-Mart' 99) (İstanbul: İş Bankası Kültür Yayınları, 2004), 303.

112 İlhan, Yildiz, 303. 
113 Galivey, Doğu ve Batı toplumlarını ve dolayısıyla sosyalizm deneyimlerinin farklı olduğunu söyler: "Müslüman halkları proleter halklardır ve örneğin İngiliz ve Fransız proleterleri ile Afgan veya Faslı proleterler arasında muazzam bir fark vardır. Dolayısıyla, denilebilir ki Müslüman ülkelerdeki ulusal kurtuluş savaşları bir sosyalist devrim niteliği taşır". Ayrıca bkz. Alexandre Benningsen, Lemercier Chantal Quelquejay, Sultan Galiyev ve Sovyet Müslümanları (Ankara: Elips, 2005), 119.

114 İlhan Haziran 1975'te kaleme aldığı bir yazısında şunları söyler: “Fakat benim kafamı bir de ne kurcalıyor bilin bakalım. Sultan Galiyev'in yarı sömürge toplumların ulusal demokratik devrim ve kurtuluş savaşlarını yorumlayan savlarıyla, Mustafa Kemal'inkiler arasındaki müthiş yakınlık!". Ayrıca bkz. İlhan, Hangi Atatürk, 305.

115 Milli demokratik devrim tezinin oluşmasında solun 1960'larda Türkiye'nin emperyalist tehditten kurtulamamış ve hatta feodal yanı ağır basan yarı sömürge bir ülke konumunda olduğu şeklindeki tespitleri ve bunun ardından feodalizm, emperyalizm ve onun içerideki işbirlikçileri olarak komprador burjuvaziye yönelik bir mücadelenin zorunluluğu düşüncesi hakimdir. Ayrıca bkz. Belli, Milli, 35-36; Doğan Avcıŏlu, "Cumhuriyetin 42. Yılında," Yön 135 (1965): 3. Dolayısıyla tam bağımsız bir Türkiye'de sosyalizmin kurulması için ilk aşama Atatürkçülük/Kemalizm ile yapılacak bir ittifak olarak belirginleşmekteydi. Avcıŏlu bunu, Türkiye'nin içinde bulunduğu şartlarda hızla kalkınması ve çağdaş uygarlık düzeyine bir an önce ulaşması için tek çare olarak gördükleri millî devrimci kalkınma yolunun Kemalist tezin temele indirilmesi ve böylece Atatürk devrimlerinin devam ettirilmesi olarak dillendirmektedir. Ayrıca bkz. Avcıoğlu, Türkiye'nin, 526.

116 Aşamalı devrimden yana olan Milli demokratik devrim hareketi, Türkiye'nin geri kalmış ve demokrasi yoksunu bir ülke olarak önündeki aşamanın sosyalist değil demokratik devrim; sosyalizmin mevcut meselesinin de sosyalist değil, antiemperyalist ve antifeodal mücadele olduğunu söylemektedir. Ayrıca bkz. Aydınoğlu, Türkiye'nin, 202; Avcıŏlu, "Sosyalist”, 20. TiP çevresi ise Türkiye'nin doğrudan bir saldırı savaşı ile değil, yeni sömürgecilikle karşı karşıya olduğundan antiemperyalist mücadele ile sosyalist mücadelenin birbirinden ayrılmaması gerektiğini, yani emperyalizme karşı savaş ile sosyalizm için savaşın bir arada gitmesi gerektiğini iddia etmektedirler. Ayrıca bkz. Naci, Bağımsızlıktan, 7.

117 İlhan, Hangi Atatürk, 188.

118 Belli, Milli, 20.

119 İlhan, Hangi Sol, 149.

120 İlhan, Hangi Atatürk, 115.

121 İlhan, Hangi Atatürk, 139.

122 İlhan, Sultan, 73.

123 İlhan, Hangi Atatürk, 24.

124 İlhan, Sultan, 73.

125 İlhan, Hangi Atatürk, 24.

126 Aliye, Mavi, 172. 
127 İlhan, Hangi Atatürk, 19.

128 İlhan, Bir, 94.

129 İlhan, Bir, 94.

130 Avcıoğlu, "Sosyalizm", 3.

131 Avcıŏlu, "Milliyetçilere," 20.

132 İlhan, Bir, 95.

133 Şener, Türkiye, 359.

134 Özkan Ağtaş, “Ortanın Solu: İsmet İnönü'den Bülent Ecevit'e, “Modern Türkiye'de Siyasi Düşünce Cilt 4: Milliyetçilik içinde, der. Murat Belge (İstanbul: İletişim, 2007), 198.

135 İlhan, Hangi Sol, 117-118.

136 İlhan, Hangi Sol, 70.

137 İlhan, Bir, 95.

138 Attila İlhan, Sosyalizm Asıl Şimdi (İstanbul: İş Bankası Kültür Yayınları, 2005), 50.

139 İlhan, Hangi Sol, 49.

140 İlhan, Gerçekçilik, 88.

141 Etiene Balibar, Irk, Ulus, Sınıf, çev. Nazlı Ökten (İstanbul: Metis, 2007), 62.

142 İlhan, Hangi Batl, 273

143 Ahmet İnsel, “Ulusalcı Türk Solu,” Radikal, 3 Ağustos 2003, 6.

144 İlhan, Dönek, 18.

145 Sarmaşık, Attila İlhan: Açtırma, 164.

146 İlhan, Hangi Să̆, 213. 
$120<$ ilef dergisi 